\title{
In vitro efficacy of teat antiseptics against Staphylococcus aureus strains isolated from bovine mastitis
}

\section{Eficácia in vitro de antissépticos utilizados no controle da mastite bovina frente a isolados de Staphylococcus aureus}

\author{
Renata Paoli Santos ${ }^{*}$; Fernando Nogueira Souza ${ }^{2}$; Carla Gasparotto Chande \\ Vasconcelos $^{3}$; Adriana Cortez ${ }^{4}$; Dalila Lapinha Silva Oliveira Rosa ${ }^{2}$; Annatachi \\ Botelho Jardim ${ }^{5}$ Adriano França Cunha ${ }^{2}$; Ângela Maria Quintão Lana; \\ Marcos Bryan Heinemann ${ }^{7}$; Mônica Maria Oliveira Pinho Cerqueira ${ }^{8}$
}

\begin{abstract}
The process of teat disinfection is a widely accepted component of successful mastitis control programs by reducing the number of bacteria on the teat skin and healing teat lesions. For contagious pathogens such as Staphylococcus aureus, post-milking teat disinfection remains a simple, effective and economical practice for prevention of new intramammary infections (IMIs) of lactating dairy cows. Despite the universal acceptance of teat dipping as a method of mastitis control, variations in the susceptibility and resistance profile of mastitis pathogens among antiseptics have been described. Thus, here we sought to explore the in vitro efficacy of the followings antiseptics against $S$. aureus isolated from IMIs: chlorhexidine $(2.0 \%)$, chlorine $(2.5 \%)$, quarternary ammonium $(4.0 \%)$, lactic acid $(2.0 \%)$ and iodine $(0.6 \%)$. We used $50 \mathrm{~S}$. aureus strains isolated from bovine IMIs from 50 dairy herds located at Minas Gerais, São Paulo, Paraná and Rio Grande do Sul States (Brazil). The antiseptics were evaluated at four different specific intervals $(15,30,60$ and $300 \mathrm{~s})$. We found a higher activity for quarternary ammonium and chlorhexidine against $S$. aureus at all time-points, followed by iodine and then chlorine. Lactic acid treatment produced the worst results for all time-points and strains. Due to variations in the sensitivity and resistance profile of antiseptics against S. aureus isolated from IMIs, the effectiveness of the antiseptics against the major mastitis pathogens should be periodically evaluated in dairy farms in an attempt to reduce the rate of new IMIs in the herd.
\end{abstract}

Key words: Dairy cow. Intramammary infection. Milking. Teat dip. Antiseptics.

\footnotetext{
${ }^{1}$ Discente do Curso de Mestrado do Programa de Ciência Animal, Escola de Veterinária da Universidade Federal de Minas Gerais, EV/UFMG, Belo Horizonte, MG, Brasil. E-mail: renatadepaoli@yahoo.com.br

${ }^{2}$ Drs., em Ciência Animal, EV/UFMG, Belo Horizonte, MG, Brasil. E-mail: nogueirasouza@yahoo.com.br; dalila.1so.rosa@ gmail.com; adrianofcunha@hotmail.com.br

${ }^{3} \mathrm{Dr}^{\mathrm{a}}$, em Doenças Tropicais, Laboratório VIDAVET, Botucatu, SP, Brasil. E-mail: labvidavet@hotmail.com

${ }^{4}$ Prof $^{a}$ Dra $^{\text {a }}$. Curso de Medicina Veterinária, Universidade Santo Amaro, São Paulo, SP, Brasil. E-mail: cortez.adri@yahoo.com.br

${ }^{5}$ Médica Veterinária, EV/UFMG, Belo Horizonte, MG, Brasil. E-mail: annatachi@gmail.com

${ }^{6}$ Prof $^{\mathrm{a}}$ Dr$^{\mathrm{a}}$, Departamento de Zootecnia, EV/UFMG, Belo Horizonte, MG, Brasil. E-mail: angelaquintao@gmail.com

${ }^{7}$ Prof. Dr., Departamento de Medicina Veterinária Preventiva e Saúde Animal, Faculdade de Medicina Veterinária e Zootecnia, Universidade de São Paulo, São Paulo, SP, Brasil. E-mail: marcosbryan@usp.br

${ }^{8}$ Prof $^{\text {a }}$ Dra $^{\text {a }}$, Departamento de Tecnologia e Inspeção de Produtos de Origem Animal, EV/UFMG, Belo Horizonte, MG, Brasil. E-mail: monicamopc@ufmg.br

* Author for correspondence
} 


\section{Resumo}

O processo de antissepsia dos tetos é uma prática amplamente recomendada no controle da mastite por reduzir o número de bactérias na pele do teto e curar lesões de teto pré-existentes. Para patógenos contagiosos como o Staphylococcus aureus, a antissepsia dos tetos após a ordenha permanece como uma prática simples, efetiva e economicamente viável na prevenção de novas infecções intramamárias (IMIs). No entanto, variações do perfil de susceptibilidade de patógenos causadores de mastite aos antissépticos têm sido descritas. Desta forma, o presente estudo objetivou avaliar a eficácia in vitro dos antissépticos a base de iodo $(0,6 \%)$, cloro $(2,0 \%)$, clorexidine $(2,5 \%)$, compostos quartenários de amônio $(4,0 \%)$ e ácido láctico $(2,0 \%)$ utilizados no pré- e pós-dipping em isolados de Staphylococcus aureus de casos de IMIs. Utilizou-se 50 isolados de $S$. aureus provenientes de 50 propriedades leiteiras localizadas nos Estados de Minas Gerais, São Paulo, Paraná e Rio Grande do Sul - Brasil. Os antissépticos foram avaliados em quatro tempos distintos $(15 \mathrm{~s}, 30 \mathrm{~s}, 60 \mathrm{~s}$ e $300 \mathrm{~s})$. Os resultados apontaram para maior eficácia dos compostos quartenário de amônio e do clorexidine, seguido pelo iodo e cloro contra os isolados de $S$. aureus nos momentos avaliados. O ácido láctico apresentou a menor atividade antisséptica em todos os momentos avaliados. Desta forma, devido a variações no perfil de susceptibilidade e resistência dos isolados de $S$. aureus isolados de casos de mastite bovina aos antissépticos, a eficácia dos antissépticos contra os patógenos primários causadores de mastites devem ser periódicamente avaliada na tentativa de reduzir a taxa de novas infecções intramamárias no rebanho.

Palavras-chave: Bovinos leiteiros. Desinfetante de teto. Infecção intramamária. Ordenha.

Mastitis is one of the most common and detrimental diseases that effect the entire milk production chain. Mastitis threatens the income of farmers as well as the image of the dairy sector, largely because of animal welfare issues and issues related to milk quality and public health due to an increased risk of antimicrobial residues and the emergence of resistant bacteria (LANGONI, 2013). Among the mastitis pathogens, Staphylococcus aureus remains the most important cause of bovine mastitis worldwide (BARKEMA et al., 2006).

The process of teat disinfection is a widely accepted component of successful mastitis control programs by reducing the number of bacteria on the teat skin and healing teat lesions. For contagious pathogens such as $S$. aureus, post-milking teat disinfection remains a simple, effective and economical practice for the prevention of new intramammary infections (IMIs) of lactating dairy cows (AMARAL et al., 2004; BARKEMA et al., 2006; PICCININI et al., 2009; WILLIAMSON; LACY-HULBERT, 2013).

Despite the universal acceptance of teat dipping as a method of mastitis control, a number of limitations are associated with most teat dips currently available. The most significant restriction is that teat dips do not provide equal protection against the huge amount of bacteria that cause bovine mastitis. Furthermore, prolonged in vitro exposure to germicidal teat dips has been shown to enhance the resistance of some bacteria to chemical antiseptics (OLIVER et al., 1990; AZIZOGLU et al., 2013). Several passages of bacterial isolates with sub-lethal concentrations of antiseptics were found to either induce resistance or select for resistant variants (BEHIRY et al., 2012). As a result, variations in the susceptibility and resistance profile of mastitis pathogens among antiseptics have been reported (MEDEIROS et al., 2009; COUTINHO et al., 2012; RAMALHO et al., 2012; AZIZOGLU et al., 2013).

The present study evaluated the in vitro efficacy of chlorhexidine $(2.0 \%)$, chlorine $(2.5 \%)$, quarternary ammonium (4\%), lactic acid $(2.0 \%)$ and iodine $(0.6 \%)$ against $S$. aureus isolated from mastitic milk.

Previous studies have investigated the susceptibility of $S$. aureus isolated in Brazil against antiseptics, however, these studies have used a limited number of $S$. aureus strains (PEDRINI; MARGATHO, 2003; RAMALHO et al., 2012) or dairy herds, and covered bacteria strains isolated 
from a relatively small region (MEDEIROS et al., 2009).

In the present study, we analyzed fifty $S$. aureus strains isolated from IMIs. Investigations into the ability to spread within quarters and cows, and cause persistent IMIs, revealed that one strain of $S$. aureus predominates in each individual herd; although the predominant $S$. aureus strain usually coexists with other S. aureus strains (SMITH et al., 1998; ZADOKS et al., 2000; BARKEMA et al., 2006).

Targeting these specific strains may be beneficial in controlling mastitis within a given herd. Thus, in this study, in an attempt to achieve a representative sampling, we selected one strain of $S$. aureus per herd totaling $50 \mathrm{~S}$. aureus strains from 50 dairy herds to determine the antiseptic efficacy. Furthermore, the $S$. aureus strains used here covered a large geographical region, having been obtained from the Minas Gerais (60\%), São Paulo (26\%), Paraná (10\%) and Rio Grande do Sul (4\%) States (Brazil).

The effectiveness of chlorhexidine $(2.0 \%)$, chlorine $(2.5 \%)$, quarternary ammonium $(4.0 \%)$, lactic acid $(2.0 \%)$ and iodine $(0.6 \%)$, in concentrations commonly used in teat disinfection aimed at controlling bovine mastitis, were tested as previously described (MEDEIROS et al., 2009; COUTINHO et al., 2012). Briefly, $0.8 \mathrm{~mL}$ of each disinfectant in the concentrations stated above,
$0.2 \mathrm{~mL}$ of sterile milk and $1.2 \mathrm{~mL}$ of a bacteria suspension standardized in 1.0 MacFarland scale were evaluated at different times of $15,30,60$ and $300 \mathrm{sec}$. After these intervals, the bactericidal activity of the antiseptics against $S$. aureus were verified by the absence of bacteria growth at $37^{\circ} \mathrm{C}$ for $24 \mathrm{~h}$ in brain-heart infusion broth (BHI; cat. $\mathrm{n}$. CM1135B, Oxoid, UK). The bactericidal activity of antiseptics against $S$. aureus were confirmed by plating $0.1 \mathrm{~mL}$ of the $\mathrm{BHI}$ broth culture onto $5 \%$ ovine blood agar plates aerobically at $37^{\circ} \mathrm{C}$ for $24 \mathrm{~h}$.

The statistical analyses were performed by the Cochran's Q test using the Medcalc statistical software (Medcalc software, Brussels, Belgium). The bacteria growth was scored as either one (bacteria growth) or zero (no bacterial growth) for statistical analysis. The significance was set at $P \leq$ 0.05 .

Our results demonstrated that there is an effect of time exposure on the efficacy of teat antiseptics against $S$. aureus strains, except for quarternary ammonium (4.0\%) (Table 1). Here, we found higher activity of quarternary ammonium (4.0\%) and chlorhexidine $(2.0 \%)$ against $S$. aureus isolated from IMIs at all time-points, followed by iodine $(0.6 \%)$ and chlorine $(2.5 \%)$, respectively (Table 1$)$. Lactic acid $(2.0 \%)$ treatment produced the worst results in all cases (Table 1).

Table 1. Susceptibility (\%) of $S$. aureus strains isolated from bovine intramammary infections against antiseptics commonly used in pre- and post-dipping.

\begin{tabular}{ccccc}
\hline & \multicolumn{4}{c}{ Susceptibility (\%) } \\
\cline { 2 - 5 } Antiseptics & \multicolumn{3}{c}{ Time (s) } \\
\cline { 2 - 5 } & $4^{\mathrm{Bc} *}$ & 30 & $8^{\mathrm{ABd}}$ & 300 \\
\hline Lactic acid & $98^{\mathrm{Aa}}$ & $4^{\mathrm{Bc}}$ & $98^{\mathrm{Aa}}$ & $14^{\mathrm{Ac}}$ \\
Quarternary ammonium & $84^{\mathrm{Ba}}$ & $98^{\mathrm{Aa}}$ & $94^{\mathrm{Aab}}$ & $96^{\mathrm{Aa}}$ \\
Chlorhexidine & $30^{\mathrm{Cbc}}$ & $90^{\mathrm{Aba}}$ & $48^{\mathrm{ABc}}$ & $64^{\mathrm{Ab}}$ \\
Chlorine & $46^{\mathrm{Cb}}$ & $40^{\mathrm{BCb}}$ & $66^{\mathrm{ABbc}}$ & $78^{\mathrm{Aab}}$ \\
Iodine & $58^{\mathrm{BCb}}$ & & \\
\hline
\end{tabular}

*Different lower case letters designate the means with statistically significant differences $(P \leq 0.05)$ among lines (antiseptics). Capital letters indicate statistically significant differences $(P \leq 0.05)$ among columns (time). 
In agreement with our results, Kassaif et al. (2007) have reported lower in vitro bactericidal activity of iodophor-based antiseptics than antiseptics containing quarternary ammonium in a panel of common dairy associated bacteria, including S. aureus. Additionally, Azizoglu et al. (2013) observed that the response among bovine $S$. aureus strains selected as genotype group representatives based on their pulsed-field gel electrophoresis patterns to iodine varied significantly, whereas all isolates were susceptible to chlorhexidine.

Ramalhoetal.(2012)alsoidentified chlorhexidine as having the highest in vitro disinfectant activity against $S$. aureus isolated from bovine IMIs in dairy herds from the Wasteland and Forest Zone of Alagoas State (Brazil), followed by chlorine, iodine and quarternary ammonium. Medeiros et al. (2009) showed that iodine and chlorhexidine had the greatest in vitro disinfectant activity against $S$. aureus isolated from bovine IMIs in dairy herds located at the Metropolitan Recife, the Agreste and Zona da Mata regions of Pernambuco State (Brazil), followed by quarternary ammonium, lactic acid and chlorine. In light of this, the observed variation among studies into susceptibility patterns of these antiseptic against $S$. aureus isolated from bovine mastitis support the idea that it is crucial to undertake a periodic evaluation of antiseptics commonly used in dairy farms, while also considering their implications for occurrence of $S$. aureus mastitis in the herd/region studied.

In most of dairy farms, the antiseptics that are applied are commonly chosen based on the price, consumer habits and/or ease of application, and the efficacy of antiseptics against major mastitis pathogens are not usually regarded (PEDRINI; MARGATHO, 2003). Furthermore, many aspects of each antiseptic should be carefully regarded. For instance, quarternary ammonium compounds do not volatilize readily and persist on the skin, probably leading to protection between milkings. Chlorhexidine has a lesser reduction of its germicidal activity by organic material than some other common antiseptics, such as chlorine (SPINOSA et al., 2011). Improper choice of antiseptic or insufficient low concentrations can lead to natural selection of resistant bacterial isolates in the microbial population (AZIZOGLU et al., 2013), with important implications for mastitis control programs. Thus, further investigations should address antiseptic activities against the mastitis pathogens under various management strategies and across regions, and should also be focused on the appropriate minimum contact time between the antiseptics and bacteria (i.e., 30 to $60 \mathrm{~s}$ ), as well as the optimal preparation lag time in conventional milking (i.e., 60 to 90 s) (LANGONI, 2013).

\section{References}

AMARAL, L. A. do; ISA, H.; DIAS, L. T.; ROSSI JÚNIOR, L. D.; NADER FILHO, A. Avaliação da eficiência da desinfecção de teteiras e dos tetos no processo de ordenha mecânica de vacas. Pesquisa Veterinária Brasileira, Seropédica, v. 24, n. 4, p. 173177, 2004.

AZIZOGLU, R. O.; LYMAN, R.; ANDERSON, K. L. Bovine Staphylococcus aureus: dose response to iodine and chlorhexidine and effect of iodine challenge on antibiotic susceptibility. Journal of Dairy Science, Champaign, v. 96, n. 2, p. 993-999, 2013.

BARKEMA, H. W.; SCHUKKEN, Y. H.; ZADOKS, R. N. Invited review: the role of cow, pathogen, and treatment regimen in the therapeutic success of bovine Staphylococcus aureus mastitis. Journal of Dairy Science, Champaign, v. 89, n. 6, p. 1877-1895, 2006.

BEHIRY, A. E.; SCHLENKER, G.; SZABO, I.; ROESLER, U. In vitro susceptibility of Staphylococcus aureus strains isolated from cows with subclinical mastitis to different antimicrobial agents. Journal of Veterinary Science, Seoul, v. 13, n. 2, p. 153-161, 2012.

COUTINHO, L. C. A.; MEDEIROS, E. S.; SILVEIRA, N. S. S.; SILVA, L. B. G.; MOTA R. A. Eficácia in vitro de desinfetantes utilizados na anti-sepsia dos tetos frente a leveduras isoladas do leite de vacas com mastite. Pesquisa Veterinária Brasileira, Seropédica, v. 2, n. 1, p. 61-65, 2012. 
KASSAIF, Z. G.; EL HAKIM, R. G.; RAYYA, E. G.; SHAIB, H. A.; BARBOUR, E. K. Preliminary study on the efficacy and safety of eight individual and blended antiseptics against poultry and dairy indicator organims. Veterinaria Italiana, Teramo, v. 43, n. 4, p. 821-830, 2007.

LANGONI, H. Qualidade do leite: utopia sem um programa sério de monitoramento da ocorrência de mastite bovina. Pesquisa Veterinária Brasileira, Seropédica, v. 33, n. 5, p. 620-626, 2013.

MEDEIROS, E. S.; SANTOS, M. V. dos; PINHEIRO JÚNIOR, J. W.; FARIA, E. B. de; WANDERLEY G. G.; TELES, A. A.; MOTA, R. A. Avaliação in vitro da eficácia de desinfetantes comerciais utilizados no pré- e pós-dipping frente amostras de Staphylococcus spp. isoladas de mastite bovina. Pesquisa Veterinária Brasileira, Seropédica, v. 29, n. 1, p. 71-75, 2009.

OLIVER, S. P.; KING, S. H.; LEWIS, M. J.; TORRE, P. M.; MATTHEWS, K. R.; DOWLEN, H. H. Efficacy of chlorhexidine as a postmilking teat disinfectant for the prevention of bovine mastitis during lactation. Journal of Dairy Science, Champaign, v. 73, n. 8, p. 2230-2235, 1990.

PEDRINI, S. C. B.; MARGATHO, L. F. F. Sensibilidade de microrganismos patogênicos isolados de casos de mastite frente a diferentes tipos de desinfetantes. Arquivos do Instituto Biológico, São Paulo, v. 70, n. 4, p. 391-395, 2003.

PICCININI, R.; CESARIS, L.; DAPRÀ, V.; BORROMEO, V.; PICOZZI, C.; SECCHI, C.; ZECCONI, A. The role of teat skin contamination in the epidemiology of Staphylococcus aureus intramammary infections. Journal of Dairy Research, Ayr, v. 76, n. 1, p. 36-41, 2009.
RAMALHO, A. C.; SOARES, K. D. A.; SILVA, D. F. da; BARROS, M. R. C.; PINHEIRO JÚNIOR, J. W.; OLIVEIRA, J. M. B. de; MOTA, R. A.; MEDEIROS, E. S. Eficácia in vitro de desinfetantes comerciais utilizados no pré e pós-dipping frente a Staphylococcus spp. isolados em rebanhos leiteiros. Pesquisa Veterinária Brasileira, Seropédica, v. 32, n. 12, p. 1285-1288, 2012.

SMITH, T. H.; FOX, L. K.; MIDDLETON, J. R. Outbreak of mastitis caused by one strain of Staphylococcus aureus in a closed dairy herd. Journal of American Veterinary Medical Association, Washington, v. 212, n. 4, p. 553556, 1998.

SPINOSA, H. S.; GORNIAK, S. L.; BERNADINI, M. M. Farmacologia aplicada à medicina veterinária. Rio de Janeiro: Guanabara Koogan, 2011. 848 p.

WILLIAMSON, J. H.; LACY-HULBERT, S. J. Effect of disinfecting teats post-milking or pre- and post-milking in intramammary infection and somatic cell count. New Zealand Veterinary Journal, Palmerston North, v. 61, n. 5, p. 262-268, 2013.

ZADOKS, R. N.; VAN LEEUWEN, W. B.; BARKEMA, H. W.; SAMPIMON, O. C.; VERBRUGH, H.; SCHUKKEN, Y. H.; VAN BELKUM, A. Application of pulsed-field gel eletrophoresis and binarytyping as tools in veterinary clinical microbiology and molecular epidemiology of bovine and human Staphylococcus aureus. Journal of Clinical Microbiology, Washington, v. 38, n. 5, p. 1931-1939, 2000. 
